\title{
Cement Dust Air Pollution and Its Effects on Human Health in Ewekoro Local Government Area Ogun State, Nigeria
}

\author{
Adedeji Adewale $^{1}$ Oladepo Daniel Sunkanmi ${ }^{2}$ Olaleye Ayodeji ${ }^{3}$ \\ 1.Department of Earth and Mineral Science, Federal University of Technology Akure (FUTA), Nigeria \\ 2.Department of Geographical Information Science and Remote Sensing, African Regional Institute for \\ Geospatial Information Science and Technology (AFRIGIST) Ile-Ife, Nigeria \\ 3.Department of Earth and Mineral Science, Federal University of Technology Akure (FUTA), Nigeria
}

\begin{abstract}
Many developing nations like Nigeria, the causes of air pollution are numerous ranging from disposal of domestic and industrial wastes, bush burning, gas glaring, car exhaust, etc. all these activities affect well-being of human. Cement factory air pollution is classified as one of the sources of air pollution that increase respiratory diseases in community. This paper focuses on the dimensions of the spatial pattern, standards limit of gaseous pollutants $\left(\mathrm{CO}, \mathrm{CO}_{2}\right.$ and $\left.\mathrm{SO}_{2}\right)$, and health record of the community. Suspended particles were monitored using ToxiRAE II for (Carbon Monoxide and Sulphur) and ALNOR CF910 for (carbon dioxide) air sampler to assess the levels of gaseous pollutants throughout the community. Data on health was collected at the neighborhood health centers. The data was analyzed and the statistical aspect was carried on with the help of Ordinary Least Square (OLS) for the relationship between the pollutant and health record collected where the root means square $\left(\mathrm{r}^{2}\right)$ show the significance $0.010703,0.845100$, and 0.000733 for $\mathrm{SO}_{2}, \mathrm{CO}$, and $\mathrm{CO}_{2}$ respectively.
\end{abstract}

Keywords: Air pollution; Community health; Gaseous Pollutants; GIS

DOI: $10.7176 / \mathrm{JEES} / 11-11-04$

Publication date: November $30^{\text {th }} 2021$

\section{INTRODUCTION}

Clean air is one of the basic requirements of human and well-being. However, during the process of economic development, air pollution has been continues to be significant health hazard worldwide. The most common ambient air pollutants encountered in our daily life are particulate matter (PM) and gaseous pollutant such as Sulphur dioxide $\left(\mathrm{SO}_{2}\right)$, Nitrogen dioxide $\left(\mathrm{NO}_{2}\right)$, Ozone $\left(\mathrm{O}_{3}\right)$, Carbon Monoxide (CO) (AbdulKareem, 2001). Manufacturing activities are known to have a major on the environment through consumption of raw materials from natural resources, emissions to air, land and water, generation and disposal of hazardous wastes, noise pollution, consumption of natural resources in production processes. Generally, the natural environment are made up of air, water and soil and when there is release of emission of waste into any of the components pollution set in.

Cement production includes the quarrying of raw materials, milling, pyro-processing, cooling of clinker, storage, mill finishing, packaging and loading. Most of these operations are characterized by emission of greenhouse gases (GHG) and other gaseous pollutants such as nitrogen oxides (NOx), Sulphur oxides (SOx), Carbon monoxide (CO) and particulate matter (Olusegun, et al.2012). During klin firing with with high temperature, $\mathrm{NO}_{2}$ is largely produced. Oxidation of volatile sulphur that is present in raw limestone materials releases $\mathrm{SO}_{2}$ into the enviroment. Combustion of hydrocarbon fuel for energy production and the calcination of raw materials constitute the sources of $\mathrm{CO}$ and $\mathrm{CO}_{2}$ in cement plant operations (Micheal , 2015). Over the last decade, growing body of epidemiological and clinical evidence has led to a heightened concern about the potential deleterious effects of ambient air pollution on health and its relation to heart disease and stroke, several environmental air pollutants that include carbon monoxide, oxides of nitrogen, sulfur dioxide, ozone, lead and particulate matter $\left(\mathrm{PM}_{10}\right.$ and $\left.\mathrm{PM}_{2.5} \mu \mathrm{m}\right)$ pollution are associated with increased hospitalization and mortality (Brook \& Robert, 2004). The level of air pollution varies from country to country, location to location, community to community and from continent to continent (Ugwuanyi \& Obi, 2012). In developing country like Nigeria, air pollution laws are not in place and where they are in place, they are not enforced and also lack or inadequate technological knowledge and lack of environmental education among the citizens are other major reasons many developing countries have not been able to control their air quality (AbdulKareem, 2001). Since the exploration of oil and gas and other natural resources, the country have expereinced an escalation in its population growth, urbanization and industrialization, together with great increase in motorization and energy (Nwachukwu, Chukwuocha, \& Igbudu, 2012)

In the face of this development and with a good number of multinational oil companies, traffic congestion, cement industry, iron melting, telecommunication mast, etc., may contributes to the outdoor pollution (Omran , A M; El-Maghraby, S E; Mahmoud, E A; El-Eter, A M; Salem, M I; 2011). There is high demand for cement worldwide, and developing countries having higher share of demand and production, it production grew by $55 \%$ between 1990 and 2000 in developing countries and by 2020 the demand is expected to be $120-180 \%$ higher 
than 1990 this trend implies an increase in pollution unless there is a move to cleaner production techniques (Rashid, R; Moncef, L N; Slobodan , P S; 2011). Cement industries pollution is categorized into two segement i.e. the particulate matter and gaseous pollutant, this paper focused on gaseous pollutant aspect.

\section{MATERIALS AND METHODS}

\subsection{Study area}

Ewekoro is one of the sites of West African Portland Cement Company (WAPCO) with large deposits of limestone. It is one of the 21 villages in the local government in Ogun State located along Sango-Ifo-Abeokuta expressway of Ogun State of Nigeria, with about about $594 \mathrm{~km} 2$ (229 Sq.mi) of land. It is approximately located between Latitudes 6049'48" N and 706'16" North of Equator and Longitudes 30 2'56"E and 30 21'54"East of Greenwich Meridian with an average elevation of 120m (amsl) (Micheal , 2015). Climate in the area is humid tropical characterised by wet (April-November) and dry seasons (December-March). The vegetation around the cement plant is originally tropical rainforest type. Tall grasses and shrubs are becoming predominant owing to cement production activities. The area's wetland encourage massive plantation of sugarcane, which is a major source of income for local people.

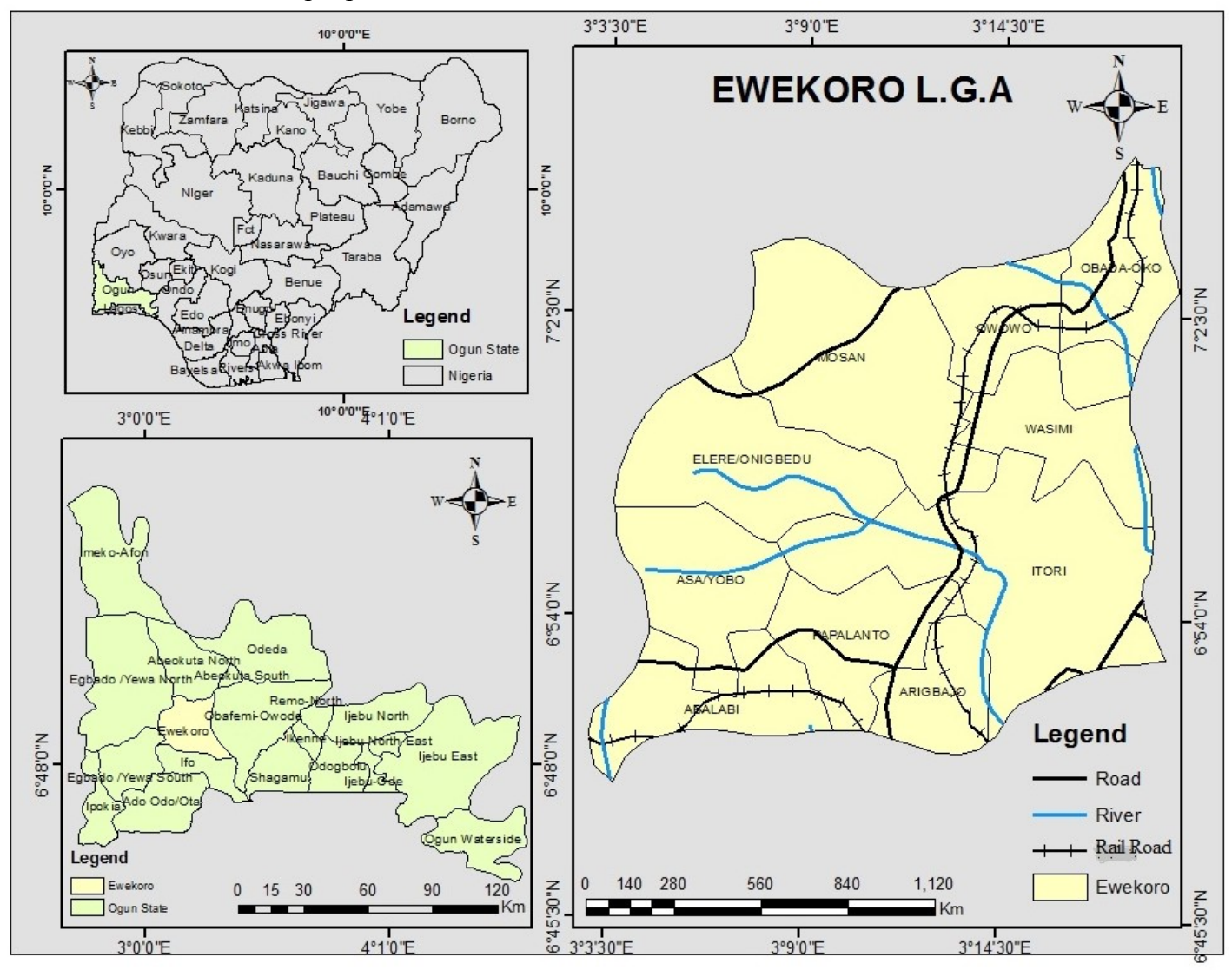

Figure 1 Location of the Study Area

\subsection{Collection of Ambient Air Quality Data}

The study area was grided and One Hundred and twenty (120) points samples points was sampled but hundread (100) points was used during the analysis using Ten (10) points from each wards. Wind speed, temperature and direction of the wind was also measured. The sample area where Bus Stops, Road Junction, Along the road, Industrial area, Markets, Residential, Streets, Hospital, and Police station. Handheld air sampler and ToxiRAE II for $\left(\mathrm{CO}\right.$ and $\left.\mathrm{SO}_{2}\right)$ \& ALNOR CF910 for $\mathrm{CO} 2$, Wind direction and temperature. A hand-held GPS Garmin 62 was also used to take the coordinate of all the points. And the air sampler was placed at breast hight. The field work was conducted in the month of March to April, 2017. 

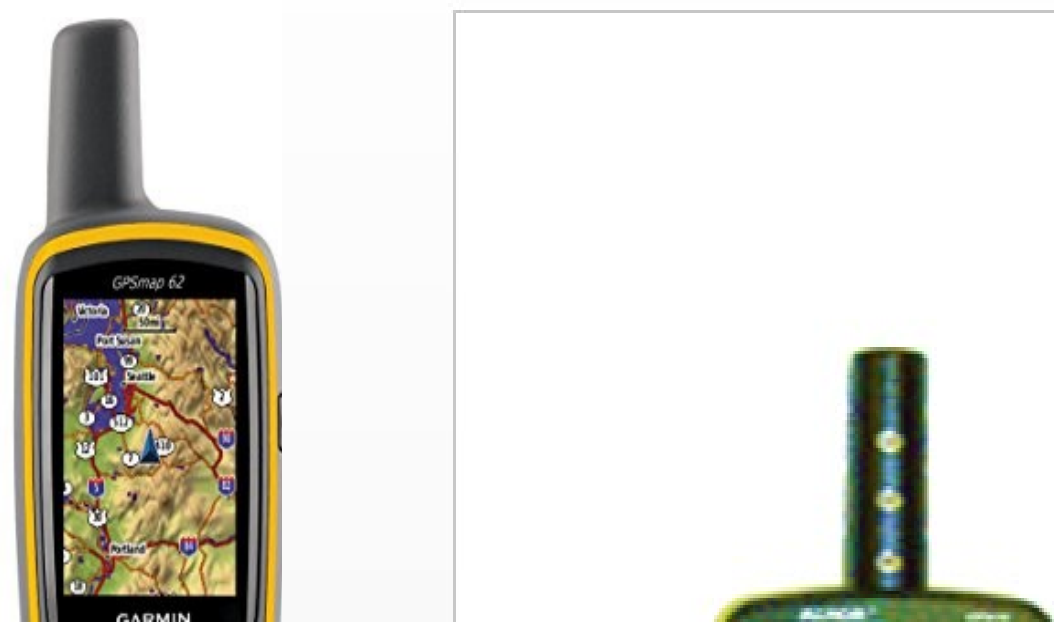

\subsection{Collection of Health Survey and Clinic Data}

The medical record of respiratory cases ailments was collected from the health care in the study area and nearby health care for the period of six (6) years (2009-2016) exclusind 2012 data from Itori Hospital. the data was in two segment 2009-2011 for ward record and 2013-2016 from Ifo local government as gender and monthly data.

\subsection{GIS and Statistical Analysis}

The use of GIS methods for examing the impact of air pollution on public health has a relatively is still in infant stage. Interpolation techniques was employed during the course of the study to estimate the output grid cell value. The health record obtained from Itori General Hospital was disaggregrated to pie chart to show the age distribution of diagnosed cases. The set of the data was disaggregated to histogram showing the gender. The measured pollutantt results was plotted with the Federal Environmental Agency (FEPA) and World Health Organisation (WHO) which some where higher than the standard limit. The statistical conducted for the relationship between the pollutant and the prevalence was carried out by Ordinary Leaste Square (OLS) and the significant showed positive correlation for the pollutant.

\section{Results and Discussion}

\subsection{Spatial Pattern of Air Pollutants Cocentration}

3.2. Carbon Monoxide (CO) Concentration and Trend

Carbon monoxide is ingested through the lungs of human and animals where it reacts with haemoglobin to reduce the blood's oxygen carring capacity which affects the delivery of oxygen to the body;s organ and tissues and causes serious problems for people with respiratory cardiovascular disease.

Increase and decrease in CO concentrations was measured during the course of the studywhich are nonuniform, higest concentration measued was $(\mathbf{1 6 . 0 3 9}) \mathbf{m g} / \mathbf{m}^{3}$ and $(\mathbf{3 9 2 . 1 5 4}) \mathbf{p p m}$, activities carry on in the ward such as heavy vehicle loading locations base, untied road that raises dust, heavy waste smoke from aluminium mining sites waste product emmitted by the cement inductry contributes to the high value gottenduring the course of the study. The maximum and minimum concentration value gotten was $(\mathbf{1 6 . 0 3 9}) \mathbf{m g} / \mathbf{m}^{3}(\mathbf{3 9 2 . 1 5 4}) \mathbf{~ p p m}$ and $(\mathbf{8 . 0 1 9}) \mathbf{~ m g} / \mathrm{m}^{3}$ (196.06455) $\mathbf{~ p p m}$ respectively are higher than the WHO and FEPA standards limit permissbile for 8hours-35hours which contributes negative effects to the health of the community at large. The concentration gotten level gooten was similary to the report of (Ajadi, 2008).

Figure 1.1 and 1.2 show the spatial concentration and geostatitical semi-variogram of carbon monoxide (CO) concentration. 


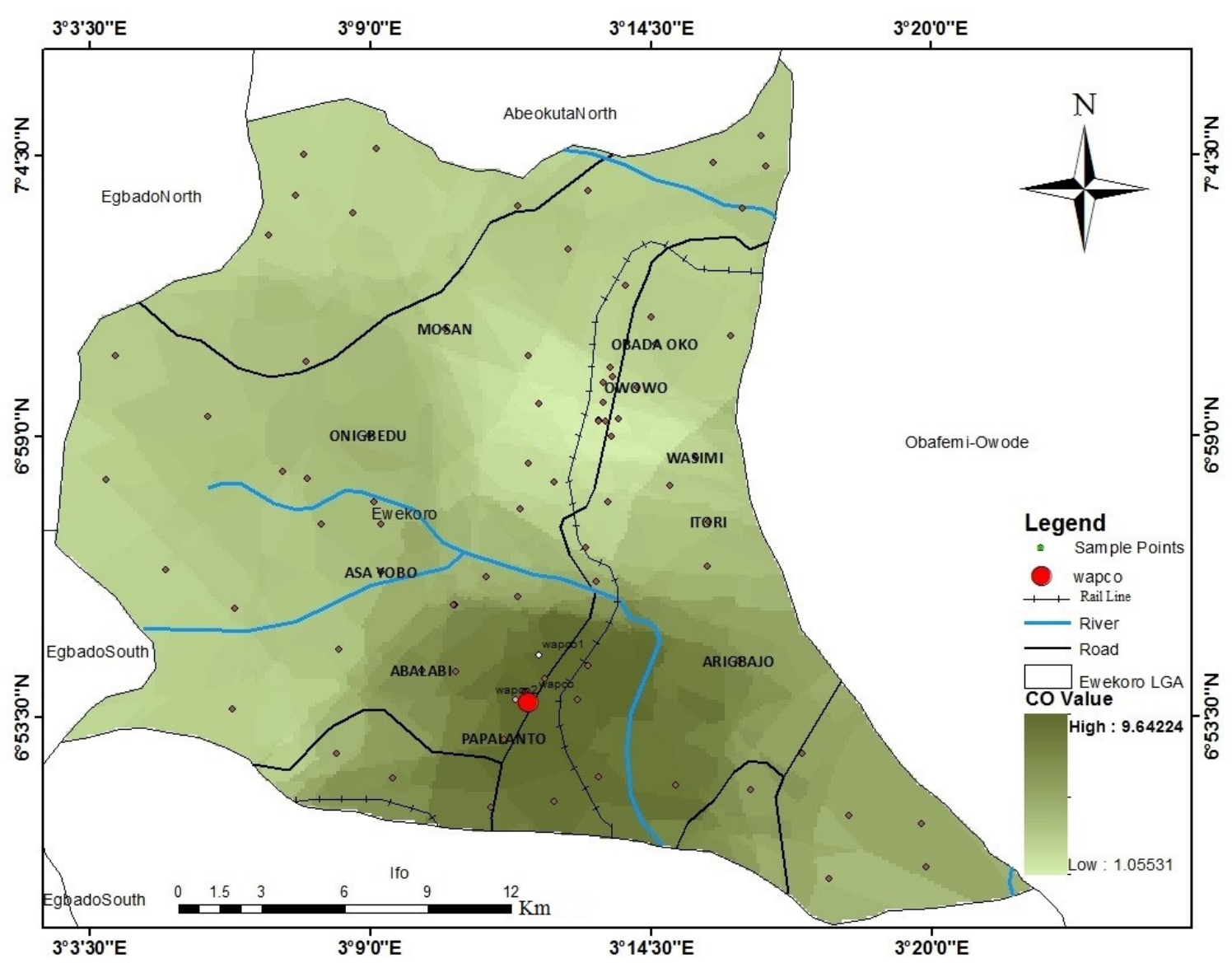

Figure 1.1 Carbon Monoxide (CO) concentration

Source: Field Work 2017

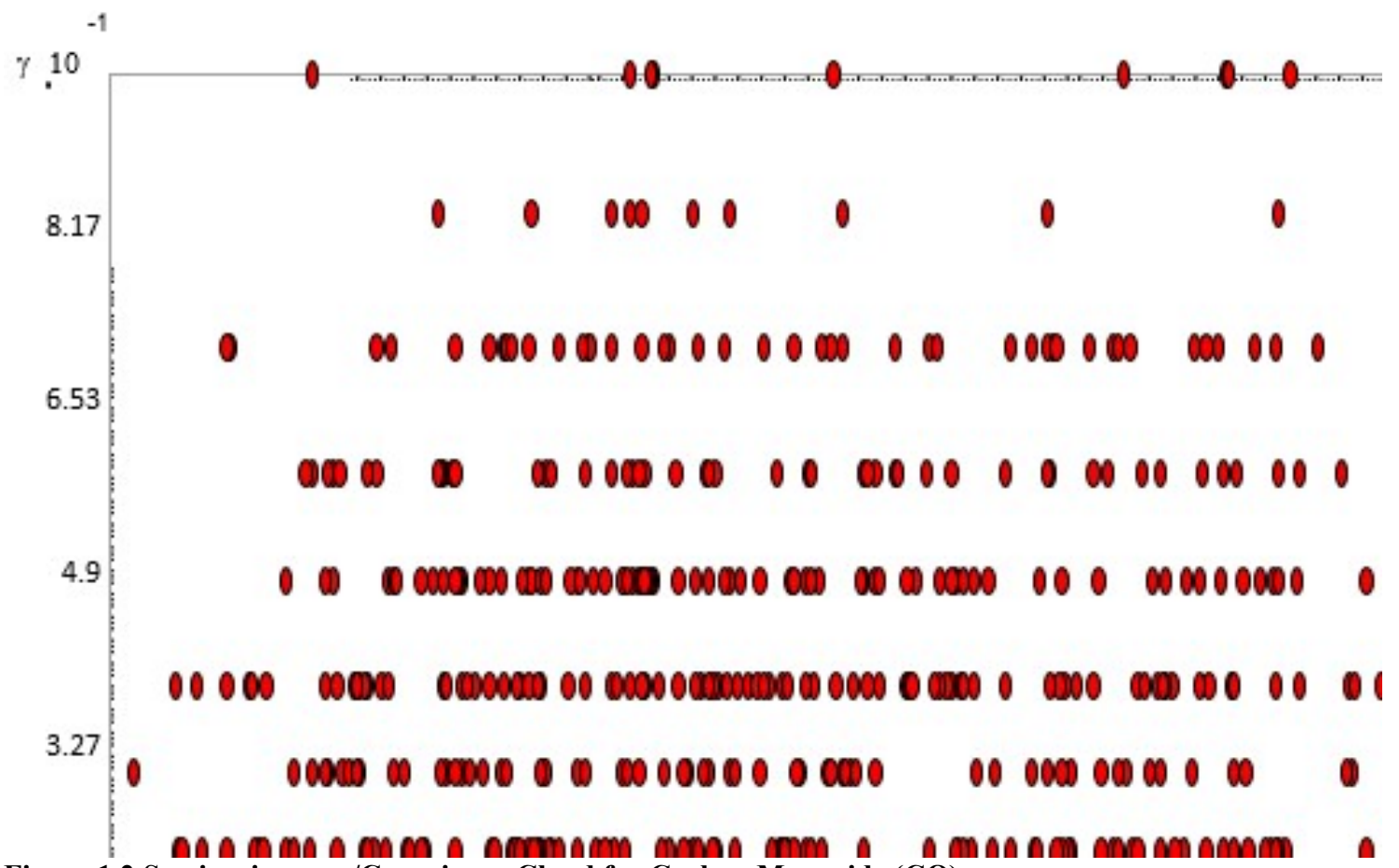

Figure 1.2 Semivariogram /Covariance Cloud for Carbon Monoxide (CO) 


\subsection{Concentration and Trend of Carbon dioxide $\mathrm{CO}_{2}$}

The concentration measured around the cement industry area was higher than that of neighboring wards where industrial activates is not too engage. (644.396) $\mathrm{mg} / \mathrm{m} 3(15755.5) \mathrm{ppm}$ for the maximum and (269.998) $\mathrm{mg} / \mathrm{m} 3$ (6601.5) for the minimum concentration. Pollutant does not recognize political wards boundaries, the direction of wind, weather condition, topography, air upthrust depict movement of pollutant per time and the height of the stack determine the neighbor community the pollutant will affect most the higher the stack the preventive it is to the community within but have greater in another community.

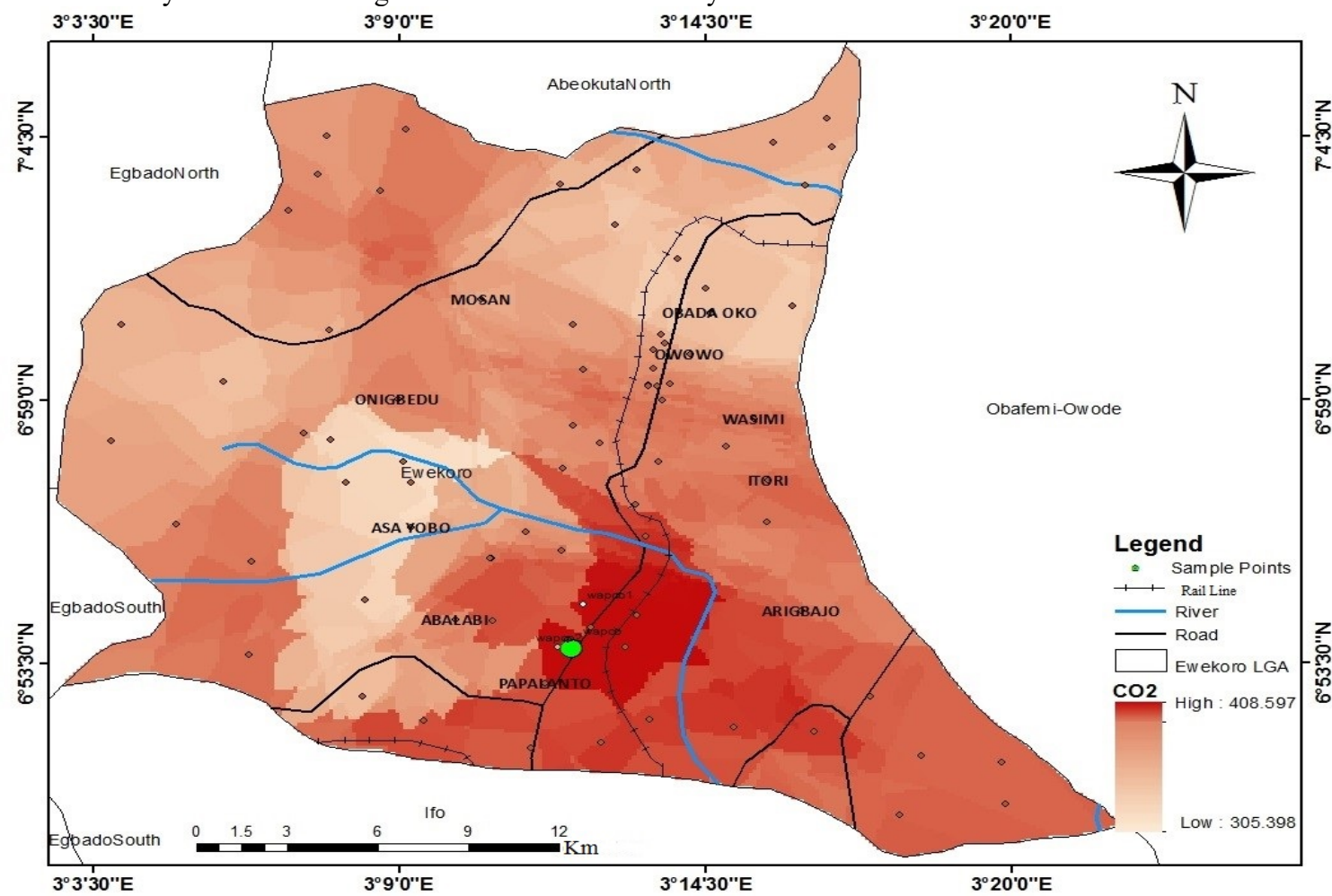

Figure 1.3 Carbon Dioxide $\left(\mathrm{CO}_{2}\right)$ concentration

Source: Field Work 2017

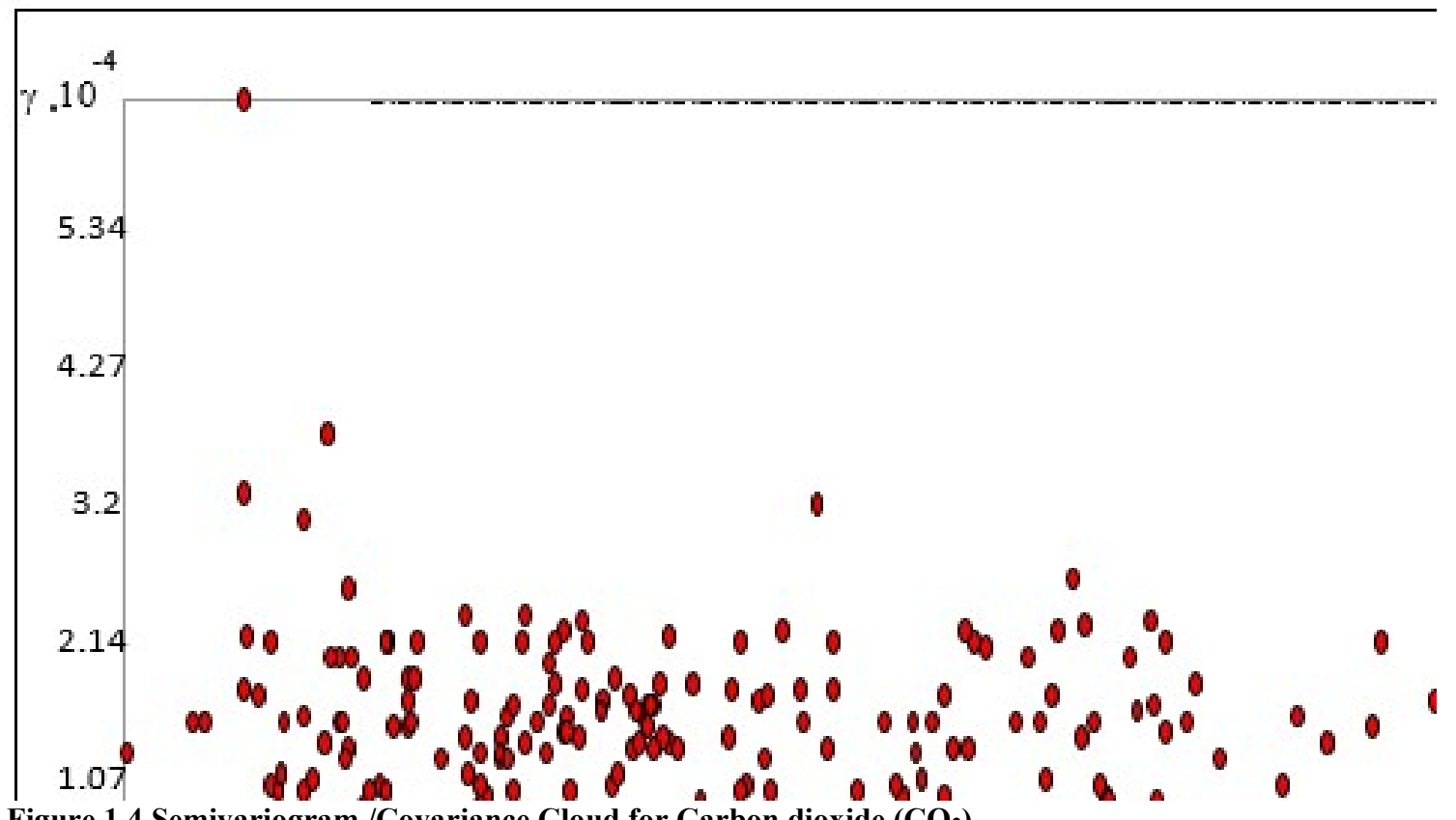

Figure 1.4 Semivariogram /Covariance Cloud for Carbon dioxide $\left(\mathrm{CO}_{2}\right)$ 
3.4 Concentration and Trend of Sulphur dioxide $\mathrm{SO}_{2}$

Process of sulphuric acid in the upper atmoshpere contributes to the acid rain, and the low level of it affects human health by causing respiratory irritation disease and also damange vegetation and other part of the ecosystems (Bert, B; Holgate, T S, 2002). The concentration of SO2 measured during the course of study was higher than the standard limit of $\mathbf{0 . 7 p p m}$ set by WHO and $\mathbf{0 . 5 p p m ~ F E P A ~ w i t h i n ~} 24$ hour range. Despite sulphur disolve quickly to $\mathrm{SO} 4$ after emitted from the source but the level of SO2 is still stong in the environment. (15.721) $\mathrm{mg} / \mathrm{m}^{3},(\mathbf{3 . 8 4 . 3 7}) \mathrm{ppm}$ was the highest level of concentration gotten and $\left.(\mathbf{2 . 6 2 0 m}) \mathrm{g} / \mathrm{m}^{\mathbf{3}}, \mathbf{( 6 4 . 0 6 )}\right) \mathrm{ppm}$ was the lowest concentration gotten during the course of study. Figure 1.5 and 1.6 show the spatial distribution and semi-variogram respectively.

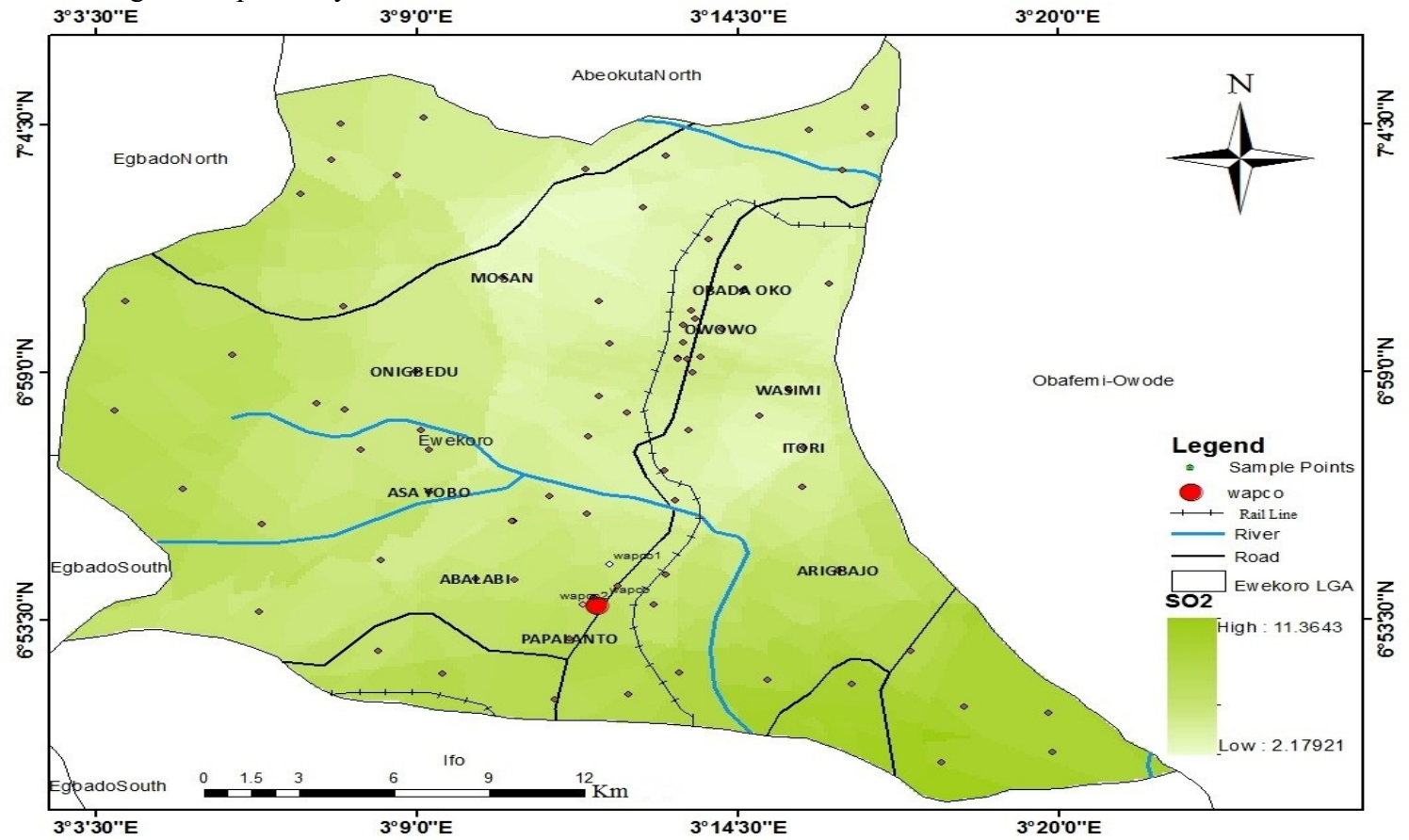

Figure 1.5 Sulphur dioxide $\left(\mathrm{SO}_{2}\right)$ Interpolation for the Study

Source: Field Work 2017

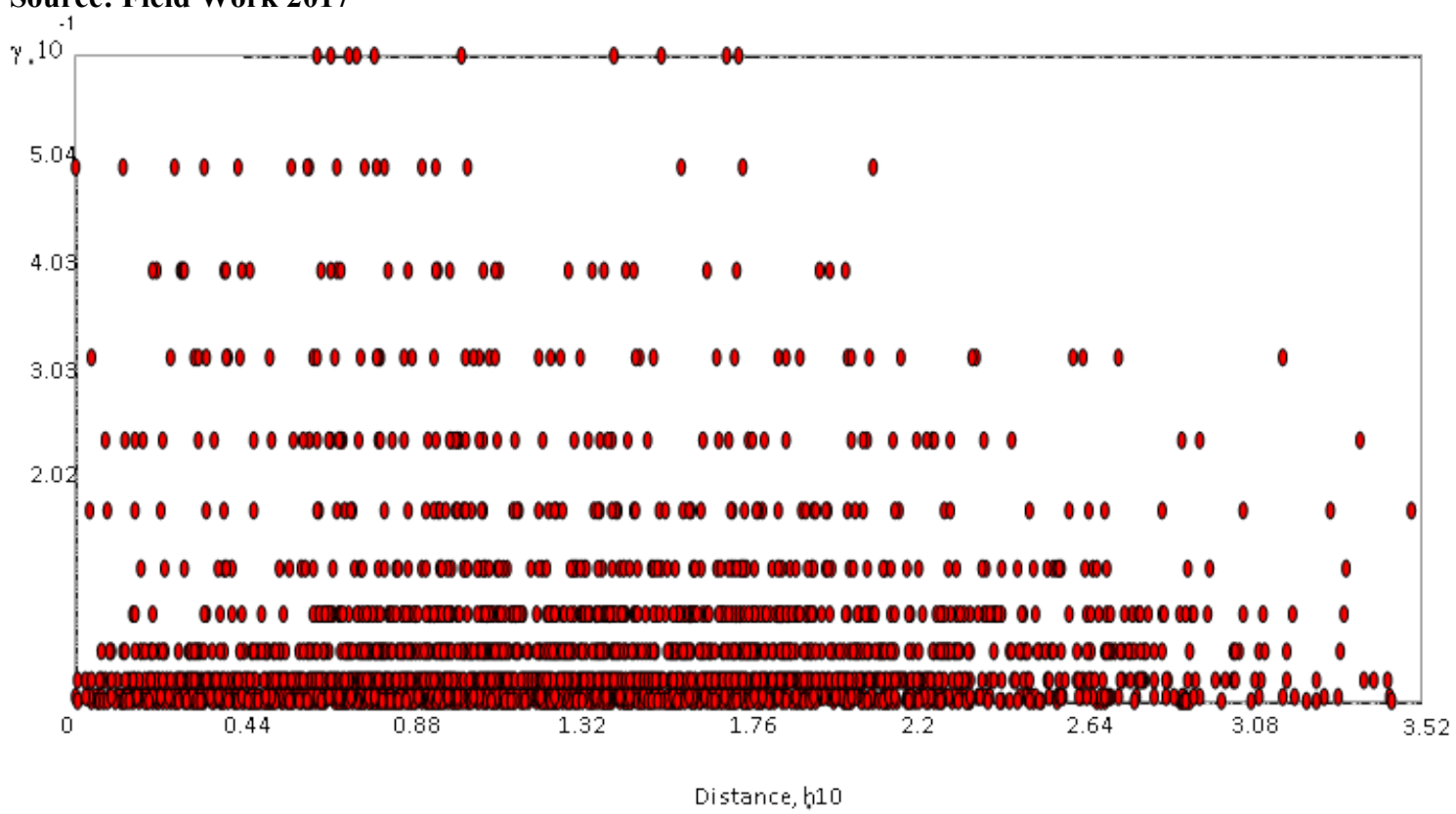

Figure 1.6 Semivariogram /Covariance Cloud for Sulphur dioxide $\mathrm{SO}_{2}$ 


\subsection{Level of Pollutant Measured vs. WHO and FEPA STANDARNDS}

From the study carried and the analysis $\mathbf{9 2 \%}$ of CO concentration falls below WHO safe limit, $\mathbf{6 \%}$ falls above the WHO safe limit and $\mathbf{2 \%}$ are above the FEPA safe limit. The concentration that falls above the safe limit where the point where heavy industrial activities are taken place the loading base emitted waste dust contributes to the high level of CO concentration and the levels of trees planted in the area are not enough so the dust easily settle on the iron sheet, human body, animal, uncovered and other vehicles packaged making the area vulnerable to assimilate dust particle. 83.71\% of the sampled point where higher than both WHO and FEPA standards safe limit, 9.50\% where above the WHO standard limit and $\mathbf{6 . 7 9 \%}$ where above the FEPA standard limit. The leve of carbon dioxide measured during the study was conducive with $\mathbf{4 7 . 7 0 \%}$ to FEPA, 33.39\% to WHO standard safe limit with $\mathbf{1 8 . 9 1 \%}$ level of carbon measured during the study.

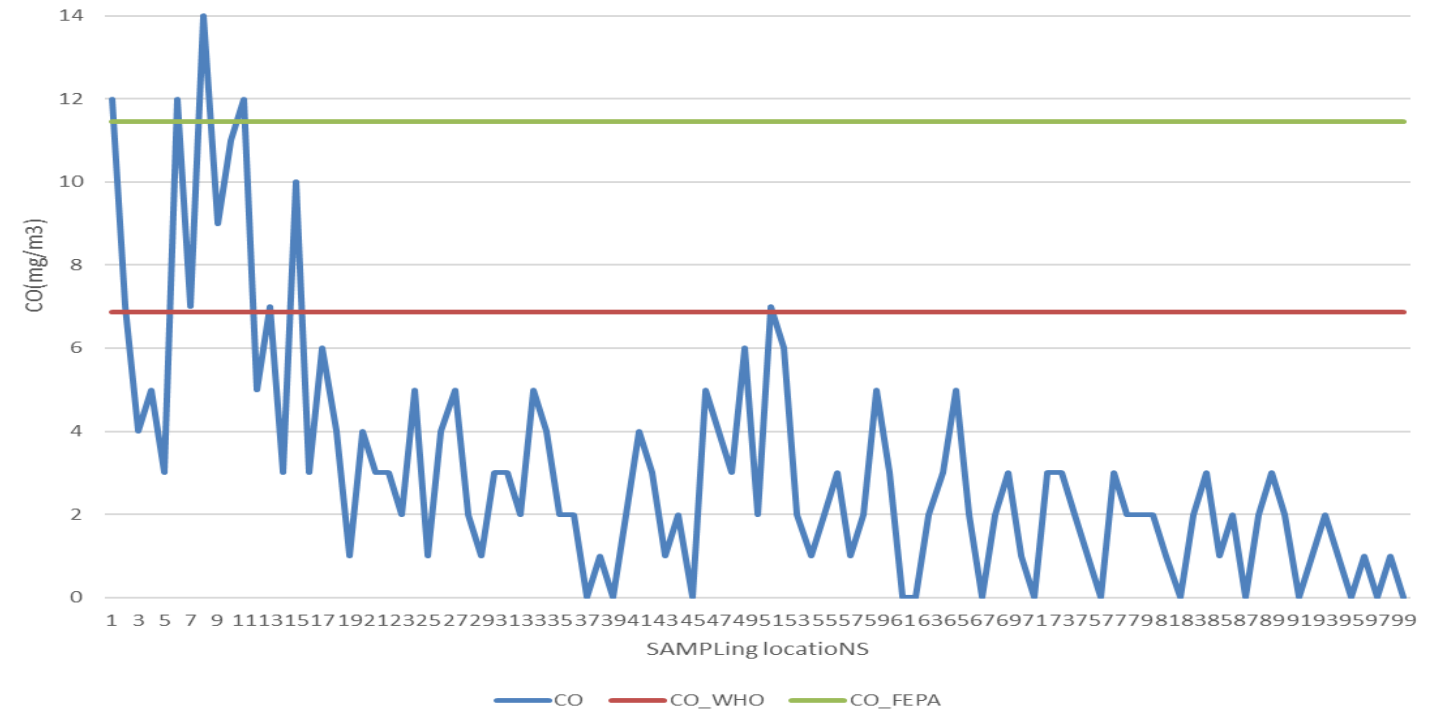

Figure 1.7: Carbon Monoxide Measured Level Compare to WHO and FEPA Standards

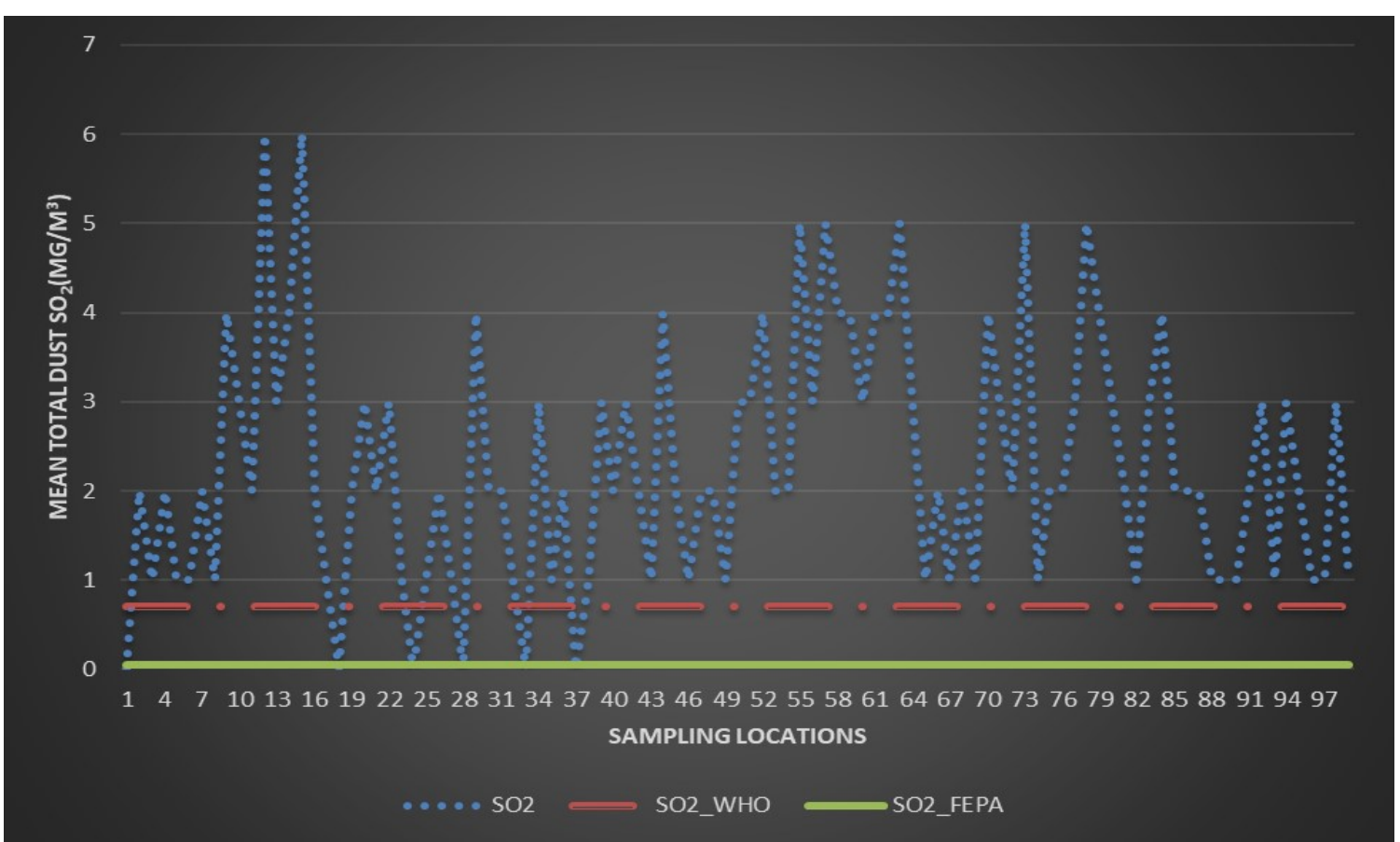

Figure 1.6 Sulphur dioxide Level Measured Compared to WHO and FEPA Standards 


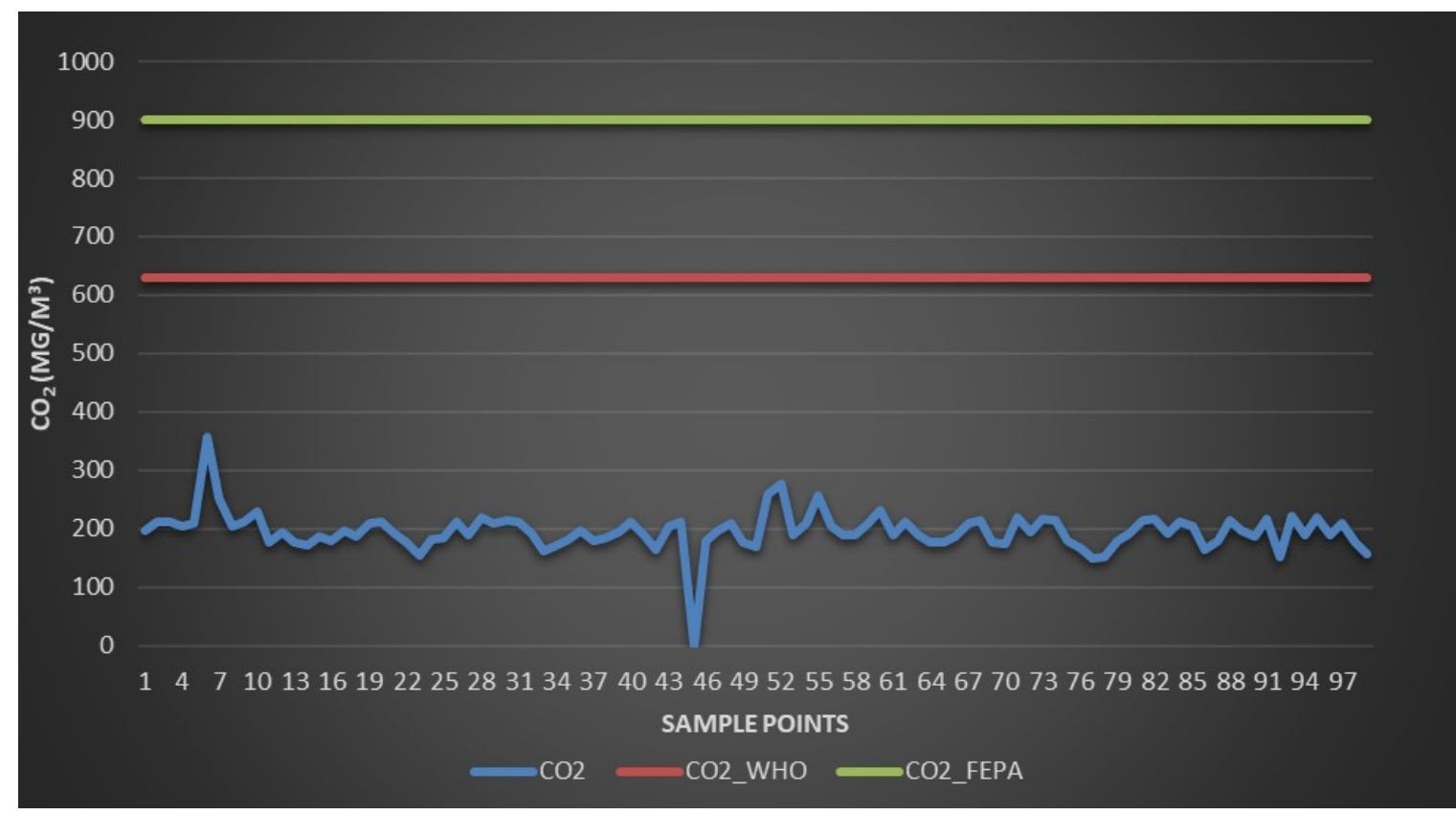

Figure 1.7 Carbon dioxide Level Measured Compared to WHO and FEPA Standards

\subsection{Respiratory Disease Data Analysis}

Two set of respiratory diseases data was gotten from the study area during the study the ward data for year 20092011 and 2013-2016. The 2009-2011 show that two communities Mosan and Itori wards have the highest number of respiratory cases in the ward. Males gender show greater percentage than females in the ward record gotten due to the activities involvement in the community and industries located in the area where carried on by male which there is no proper or inadequate protective gadget during or after work. The second set of data 20132016 show the monthly and gender there the highest cases occurred in the month of June, with $\mathbf{5 2 \%}$ of female recorded and $\mathbf{4 8 \%}$ of male recorded.

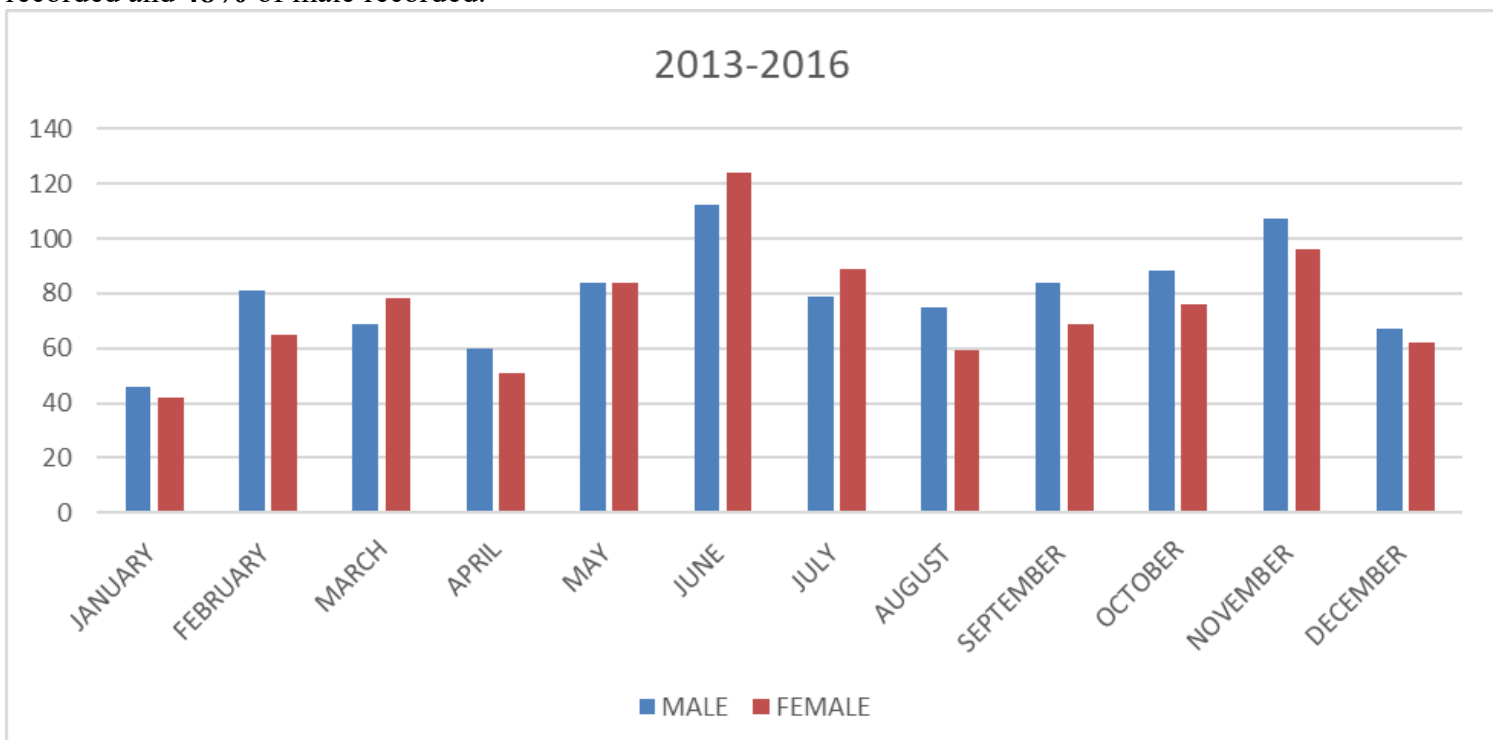

Figure 1.9 Histogram of Respiratory case for 2013-2016 


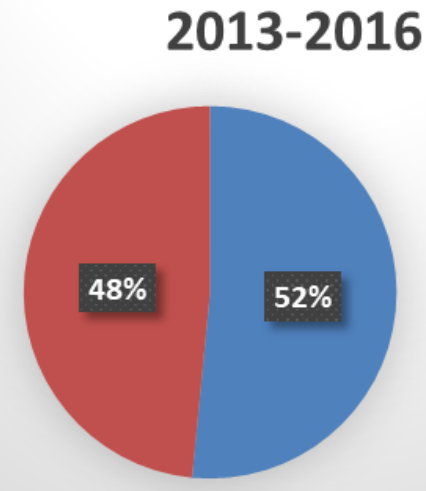

Figure 1.10 Pie-Chat Gender for 2013-2016

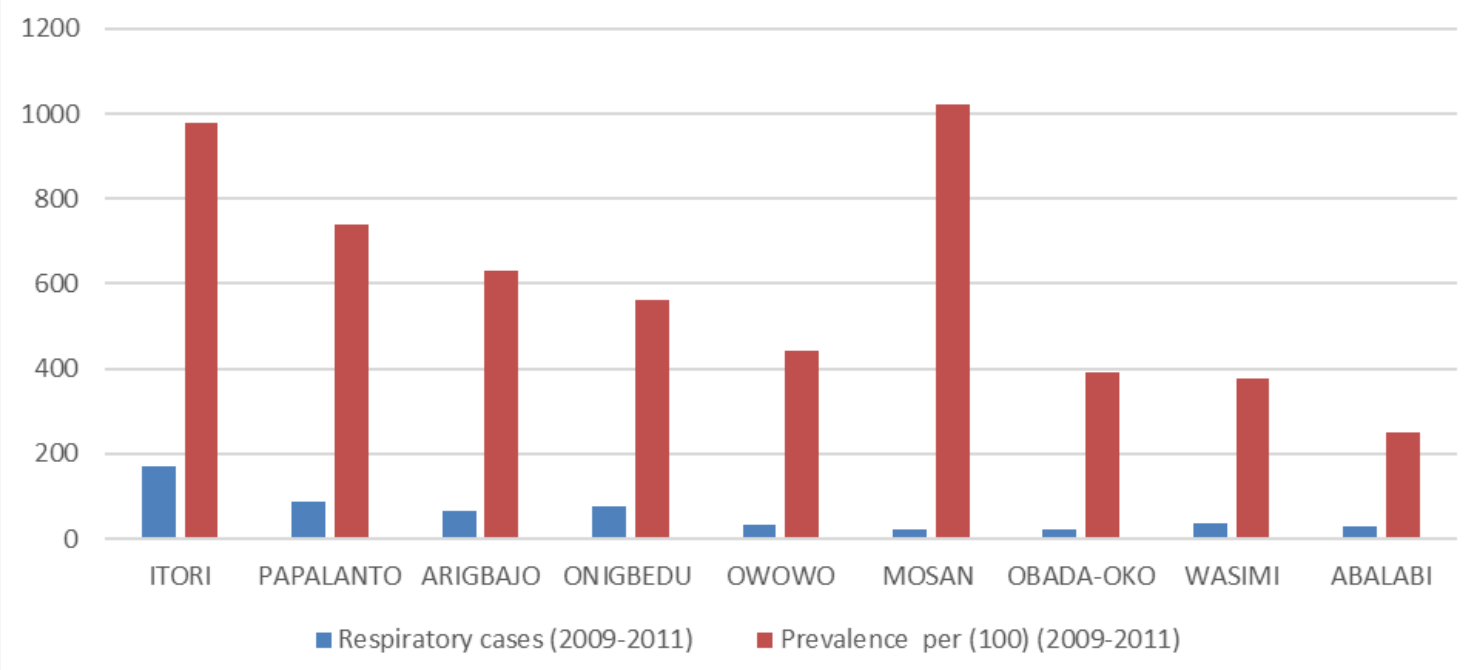

Figure 1.8 Histogram of Respiratory diseases for 2009-2011 years

a nopilatuly Lases laus

\section{Figure 13 4.10 Histogram of Respirati}

Figure 1.9 Pie chat and Gender Histogram of Respiratory Diseases for year 2009-2011 


\subsection{Relationship between the pollutant and the Distance}

The $r^{2}$ of the analysis show that the significance of each pollutants $0.010703,0.845100$, and 0.000733 for $\mathrm{SO}_{2}$, $\mathrm{CO}$, and $\mathrm{CO}_{2}$ respectively showing that $\mathrm{SO}_{2}$ contribute more significance to the health of the people in the community. Mosan ward show the highest prevalence ward having the most impact of the pollutant when the pollutant is released. Figure 1.9 show the breakdown of how the pollutant affect the community.

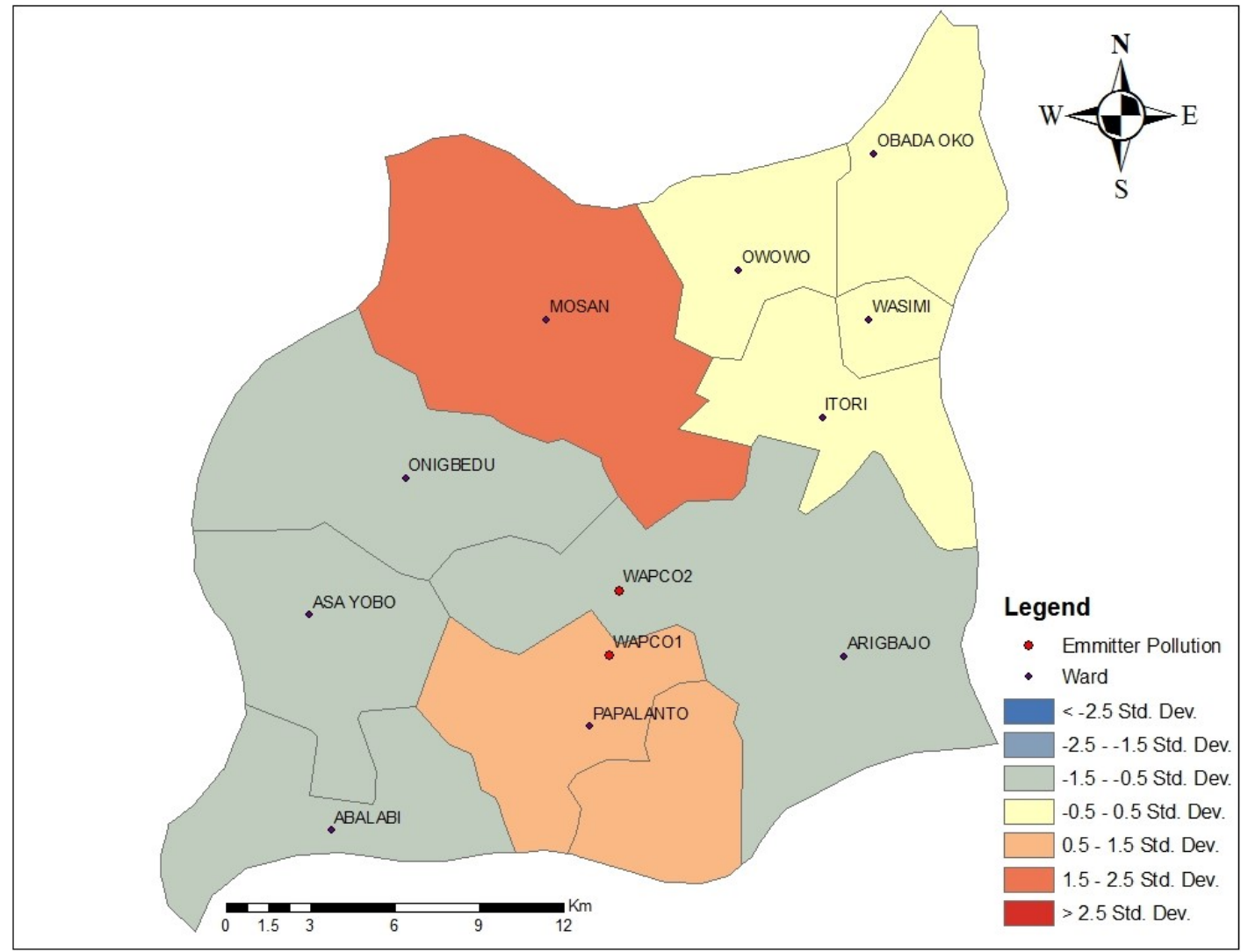

Figure 1.9 Spatial Pattern of Pollutants and Prevalence Cases

\section{Conclusion and Recommendations}

Air pollution is something that we cannot really ignore now-a-days which causes a varieties of health problem. As the number of industries keep increasing with time so also level of air pollution keep increasing with different sources. The profile of health problems suffered by the people in the community reflected in the prevalence of respiratory ailments possibly because of cement dust exposure, as confirmed by similar studies elsewhere. Although the industry workers and the residents of the community were exposed to dust pollution, lack of safety knowledge and access to protective equipment and does that are knowledgeable about the safety did not make proper use of it and lack of free medical test and care.

There is a need to enforce environmental laws and policies in the community and Nigeria at large so as to achieve more effective industrial compliance and environmental audit that incorporates surveillance of communities near to operating plants which have an environmental impact. Moreover, communities which can be ascertained to be affected by appreciable deposits of industrial pollutants, should be relocated away from the source, and the existing settlement areas acquired by the factory as a buffer zone which the prevalence in Mosan showed during the analysis and data collected. The plants very close to the factory should not be used for humans consumption such as natural medicine, feeding of animals and other related activities because those plants are contaminated with large amount of pollutant settled on them for ages. Proper awareness must be done to the community member and proper gadget should be distribute to the workers.

\section{References}

AbdulKareem, A. (2001). Urban Air Pollution Evaluation by Computer Simulation. Jpurnal of Association for the Advancement of Modelling and Simulation Techniques in Enterprieses, p2.

Ajadi, O. A. (2008). Impact of Ewekoro Cement Factory on the Surrounding Water Resources. University of 
Agriculture Abeokuta Ogun State, 087.

Bert, B; Holgate, T S. (2002). Air Pollution and Health . Science Direct, p005.

Brook, \& Robert, D. (2004). Air Pollution and Cardiovascular Disease. AHA Scientific Statement.

Micheal, A. O. (2015). Environmental Polution and Health Risks of Residents Living Near Ewekoro Cement Factory, Ewekoro,NIgeria . International Journal of Environmental, Chemical, Ecological Geologocal Engineering, 004.

Nwachukwu, A. N., Chukwuocha, E. O., \& Igbudu, O. (2012). A Survey On The Effects of Air Pollution In Diseases Of The People of Rivers State, Nigeria. Journal of Environmental Science and Technology, 004.

Olusegun, O; Abibemi, E A; Harold, J A;. (2012). Impact of Cement Factory Operations on Air Quality and Human Health in Ewekoro Local Government Area, South-Western Nigeria. International Journal of Environmental Studies, 002.

Omran, A M; El-Maghraby, S E; Mahmoud, E A; El-Eter, A M; Salem, M I;. (2011). Impact Of Cement Dust On Some Soil Properties Around The Cement Factory In Al-Hasa Oasis, Saudi Arabia. American Eurasian Journal Of Agricultural and Environmental Science, 011.

Rashid, R; Moncef, L N; Slobodan , P S;. (2011). Policy Making For Greening The ConcreteIndustry In Canada: A Systems Thinking Approach. Researchgate, 003.

Ugwuanyi, J. U., \& Obi, F. C. (2012). A Survey of Health Effects of Air Pollution On Peasant Farmers In Benue State, Nigeria. Reserachgate, 006. 